\title{
Cell-Phone Use and Self-Reported Hypertension: National Health Interview Survey 2008
}

\author{
Sivaranjani Suresh, ${ }^{1}$ Charumathi Sabanayagam, ${ }^{2}$ Sita Kalidindi, ${ }^{2,3}$ and Anoop Shankar ${ }^{2,4}$ \\ ${ }^{1}$ University Scholars Programme, National University of Singapore, Singapore 119260 \\ ${ }^{2}$ Department of Community Medicine, School of Medicine, West Virginia University, Morgantown, WV 26506, USA \\ ${ }^{3}$ Department of Statistics, School of Medicine, West Virginia University, Morgantown, WV 26506, USA \\ ${ }^{4}$ Department of Community Medicine, School of Medicine, West Virginia University, Robert C. Byrd Health Sciences Center, \\ 1 Medical Center Drive, P.O. Box 9190, Morgantown, WV 26506, USA
}

Correspondence should be addressed to Anoop Shankar, ashankar@hsc.wvu.edu

Received 29 November 2010; Revised 14 January 2011; Accepted 29 January 2011

Academic Editor: B. Waeber

Copyright ( 2011 Sivaranjani Suresh et al. This is an open access article distributed under the Creative Commons Attribution License, which permits unrestricted use, distribution, and reproduction in any medium, provided the original work is properly cited.

\begin{abstract}
Background. Cell-phone usage has increased dramatically over the last decade, along with a rising public concern over the health effects of using this device. The association between cell-phone usage and hypertension has not been examined before. Methods. We analysed data from 21,135 adults aged $\geq 18$ years who participated in the 2008 National Health Interview Survey. Based on reported cell-phone use, participants were categorized as cell-phone nonusers, predominantly landline users, dual users of cell phone and landline, and predominantly cell-phone users. The main outcome of interest was self-reported physician-diagnosed hypertension $(n=6,793)$. Results. $43.5 \%$ of the participants were cell-phone nonusers, while $13.8 \%$ were predominantly cellphone users. We found that cell-phone use was inversely associated with hypertension, independent of age, sex, race/ethnicity, smoking, alcohol consumption, education, body mass index (BMI), and physical activity. Compared to cell-phone nonusers, the multivariable odds ratio $(95 \%$ confidence interval) of hypertension was $0.86(0.75-0.98, P$ trend $=.005)$ among predominantly cell-phone users. This inverse association between cell-phone use and hypertension was stronger in women, those aged $<60$ years, whites, and those with BMI $<25 \mathrm{~kg} / \mathrm{m}^{2}$. Conclusion. We found that cell-phone usage was protectively associated with self-reported hypertension in a nationally representative sample of US adults.
\end{abstract}

\section{Introduction}

It has been reported that there are more than 285 million subscribers to cell-phone services in the US in 2009, which is more than a twofold increase from 110 million in 2000 [1]. This dramatic rise of cell-phone usage has also led to concerns over their possible adverse effects on human health. While cell phones may exert both thermal and nonthermal influences on the user, the latter has been under particular scrutiny. Cell phones transmit pulsed, radiofrequency radiation from their antennas and from circuit elements inside $[2,3]$. Because cell phones are held against the head, many studies have examined the risk that these phones pose on the brain, including cognitive function $[4,5]$ and sleep [6]. Concerns over microwave radiation effects have mainly spurred research into the relation between cell-phone usage and brain tumours, including acoustic neuroma, glioma, and meningioma. While some results have shown significant associations with several types of brain tumours $[7,8]$, most have shown a null association [9-11].

However, it is not clear if cell-phone usage is related to cardiovascular diseases (CVD). Some occupational studies have shown that chronic exposure to low-intensity electromagnetic field (EMF) is associated with increased risk of cardiac arrhythmias, acute myocardial infarction, cardiovascular mortality [12], and alteration of diurnal variation of blood pressure $[13,14]$, but others have not found such an association [15-18].

Hypertension is a common vascular condition [19] that is a strong and independent risk factor for CVD 
[20]. A German study in 1998 found that cell-phone usage was associated with an increase in resting blood pressure [21]. The independent expert group on mobile phones hypothesized that radiation from the cell phone may possibly affect the cardiovascular centers of the brainstem or the carotid body receptors involved in the control of blood pressure [3]. In contrast, studies from former Soviet Union reported that exposure to radiofrequency radiation might reduce blood pressure and heart rate alterations and low-dose EMF therapy might be beneficial in treating hypertension and angina pectoris [22]. Given the dramatic increase in cell-phone usage in the past decade, it would be of interest to further investigate the effect of using cell phones on hypertension. In this context, we examined the association between mobile-phone usage and occurrence of hypertension in a large, representative sample of US adults.

\section{Methods}

The data for this study is derived from the 2008 National Health Interview Survey (NHIS). The details of the study design, questionnaire, and methods are available online [23]. In brief, NHIS is a multistage probability sample of the civilian, noninstitutionalized population of US adults. Blacks, Hispanics, and Asians were oversampled to provide stable estimates of these groups. Information on household telephone status was obtained for 12,597 households that include one civilian adult or child. The current study is based on the sample adult core component of the NHIS survey, administered by in-person interview to randomly selected civilian adults, aged $\geq 18$ years. Of the 21,781 adults interviewed, after excluding participants who were pregnant ( $n=221)$, those with missing information on cell-phone status $(n=90)$, and on certain other variables included in the multivariable analysis $(n=335), 21,135$ were available for the current analysis.

The main outcome of interest in the current study was physician-diagnosed hypertension ascertained by an affirmative response to the question, "have you ever been told by a doctor or other health professional that you had hypertension, also called high blood pressure?" Cell-phone use was assessed from the following question asked to the survey respondent from each family: "do you or anyone in your family have a working cell phone?" Participants who had no working cell phone in the family were classified as cell-phone nonusers. Of those living in a household with both landline and cell phone, those who received very few or no calls on cell phones and mostly on landlines, were classified as predominantly landline users; those who received some on cell phone and some on landline phones were classified as dual users of cell phone and landline; those who received all or almost all calls on cell phones were classified as predominantly cell-phone users. Information on demographic factors, socioeconomic characteristics, lifestyle characteristics, and health status were obtained through a standardized questionnaire.

We examined the association between cell-phone use and hypertension in two logistic regression models: (1) the age- (years) sex-adjusted model and (2) the multivariableadjusted model, additionally adjusting for race/ethnicity, cigarette smoking, alcohol intake, body mass index (BMI), physical activity, education, and landline use. We then examined the association between cell-phone use and hypertension in subgroups of age, gender, race/ethnicity and BMI categories. Linear trends were tested using categories of cell phone use as an ordinal variable in the corresponding logistic regression model. Interactions between cell-phone use and other covariates including age, gender, race/ethnicity, BMI were examined by introducing cross-product interaction terms between cell-phone use and the covariate examined, one at a time, in the corresponding multivariable model. Likelihood ratio tests were used to assess the statistical significance of an interaction between cell phone use and a covariate. All analyses were weighted to account for the complex survey design and survey nonresponse using SUDAAN (version 8.0; Research Triangle Institute, Research Triangle Park, NC) and SAS (version 9.2; SAS Institute, Cary, NC) software.

\section{Results}

Table 1 shows the characteristics of the study participants by cell-phone usage status. $43.5 \%$ of the participants were cellphone nonusers and $13.8 \%$ were predominantly cell-phone users. Compared to subjects who were cell-phone nonusers, predominantly cell-phone users were younger, more likely to be current drinkers, or to be educated at a level higher than high school, less likely to be current smokers or physically active. Further, predominantly landline users were older, more likely to be females or non-Hispanic whites.

Figure 1 shows the prevalence of hypertension by categories of cell-phone use. The group with the highest prevalence was the predominantly landline users followed by cellphone nonusers, dual users, and predominantly cell-phone users respectively. Table 2 shows the association between cell phone use and hypertension. Increasing categories of cell-phone usage was found to be inversely associated with hypertension in both the age-, sex-adjusted model ( $P$ trend $<.0001)$, and the multivariable-adjusted model ( $P$ trend $=.005)$.

Tables 3, 4, 5, and 6 show the association between cellphone use and hypertension in subgroups of age, gender, race/ethnicity, and BMI categories. Similar to the main findings in Table 2, an inverse association was observed between cell-phone use and hypertension within subgroups of age, gender, race/ethnicity, and BMI. Although there was no statistically significant interaction by age $(P$ interaction $=.99)$, gender $(P$ interaction $=.98)$, race/ethnicity $(P$ interaction $=.24)$, and BMI $(P$ interaction $=.07)$, the association was stronger in women, those aged $<60$ years, whites, and those with BMI $<25 \mathrm{~kg} / \mathrm{m}^{2}$.

\section{Discussion}

In a contemporary sample of US adults, we found that cell-phone usage was inversely associated with self-reported hypertension independent of age, sex, race/ethnicity, 
TABLE 1: Characteristics of the participants by cell-phone use.

\begin{tabular}{|c|c|c|c|c|c|}
\hline Characteristic & $\begin{array}{l}\text { Cell-phone Nonusers } \\
\qquad(n=9,190)\end{array}$ & $\begin{array}{c}\text { Predominantly } \\
\text { landline users } \\
(n=3,606)\end{array}$ & $\begin{array}{l}\text { Dual users of cell } \\
\text { phone and landline } \\
\quad(n=5,420)\end{array}$ & $\begin{array}{l}\text { Predominantly } \\
\text { Cell-phone users } \\
(n=2,919)\end{array}$ & $P$ value \\
\hline Age, years & $44.52 \pm 0.34$ & $53.89 \pm 0.42$ & $45.98 \pm 0.27$ & $40.80 \pm 0.43$ & $<.0001$ \\
\hline Female, \% & $49.90 \pm 0.68$ & $54.34 \pm 1.01$ & $51.44 \pm 0.80$ & $50.90 \pm 1.15$ & .004 \\
\hline Smoking categories, $\%$ & & & & & $<.0001$ \\
\hline Never smoker & $55.86 \pm 0.70$ & $54.23 \pm 1.05$ & $60.80 \pm 0.86$ & $60.51 \pm 1.06$ & \\
\hline Current smoker & $25.79 \pm 0.62$ & $18.47 \pm 0.82$ & $16.46 \pm 0.64$ & $19.05 \pm 0.91$ & \\
\hline Former smoker & $18.34 \pm 0.51$ & $27.29 \pm 0.87$ & $22.74 \pm 0.73$ & $20.44 \pm 0.88$ & \\
\hline Alcohol intake, \% & & & & & $<.0001$ \\
\hline Never drinker & $23.53 \pm 0.64$ & $20.68 \pm 0.89$ & $19.90 \pm 0.70$ & $15.67 \pm 0.84$ & \\
\hline Former drinker & $15.55 \pm 0.53$ & $17.93 \pm 0.69$ & $12.56 \pm 0.56$ & $10.49 \pm 0.68$ & \\
\hline Current light drinker & $38.75 \pm 0.70$ & $41.55 \pm 1.01$ & $45.58 \pm 0.82$ & $49.11 \pm 1.13$ & \\
\hline Current moderate drinker & $14.62 \pm 0.47$ & $13.71 \pm 0.70$ & $15.84 \pm 0.65$ & $16.53 \pm 0.77$ & \\
\hline Current heavy drinker & $6.21 \pm 0.33$ & $5.05 \pm 0.45$ & $4.70 \pm 0.36$ & $6.91 \pm 0.65$ & \\
\hline Unknown drinking status & $1.34 \pm 0.14$ & $1.09 \pm 0.19$ & $1.41 \pm 0.22$ & $1.29 \pm 0.28$ & \\
\hline Race/ethnicity, \% & & & & & $<.001$ \\
\hline Non-Hispanic whites & $63.54 \pm 0.82$ & $76.24 \pm 0.85$ & $71.61 \pm 0.85$ & $66.01 \pm 1.15$ & \\
\hline Non-Hispanic blacks & $13.86 \pm 0.59$ & $8.72 \pm 0.48$ & $10.36 \pm 0.56$ & $11.48 \pm 0.77$ & \\
\hline Mexican Americans & $16.45 \pm 0.59$ & $9.92 \pm 0.59$ & $11.35 \pm 0.59$ & $15.43 \pm 0.82$ & \\
\hline Others & $6.16 \pm 0.35$ & $5.13 \pm 0.43$ & $6.68 \pm 0.40$ & $7.08 \pm 0.57$ & \\
\hline Education categories & & & & & $<.0001$ \\
\hline$<$ high school & $21.43 \pm 0.64$ & $14.39 \pm 0.76$ & $11.16 \pm 0.59$ & $9.74 \pm 0.79$ & \\
\hline high school & $29.35 \pm 0.68$ & $31.23 \pm 0.99$ & $25.43 \pm 0.74$ & $22.39 \pm 1.02$ & \\
\hline >High school & $49.22 \pm 0.82$ & $54.38 \pm 1.03$ & $63.42 \pm 0.87$ & $67.87 \pm 1.18$ & \\
\hline Physical activity, $\%$ & $53.18 \pm 0.78$ & $45.08 \pm 1.05$ & $42.57 \pm 1.09$ & $38.74 \pm 1.30$ & $<.0001$ \\
\hline Body mass index, $\mathrm{kg} / \mathrm{m}^{2}$ & $29.65 \pm 0.20$ & $30.12 \pm 0.29$ & $29.78 \pm 0.21$ & $28.92 \pm 0.25$ & .2 \\
\hline
\end{tabular}

Data presented are row percentages or mean values \pm SE.

${ }^{*} P$ value represents differences in means $(\mathrm{SD})$ or proportions, using analysis of variance or Chi-square test.

TABLE 2: Association between cell-phone use and hypertension.

\begin{tabular}{lcccc}
\hline Cell-phone use & Sample size & Weighted prevalence, $\%^{\dagger}$ & Age-adjusted OR (95\% CI) & Multivariable OR (95\% CI)* \\
\hline Hypertension & & & & \\
$\quad$ Cell-phone nonusers & 9190 & 32.71 & 1 (Referent) & $1($ Referent) \\
Predominantly landline users & 3606 & 43.01 & $0.99(0.89-1.09)$ & $1.05(0.92-1.19)$ \\
Dual users of cell phone and landline & 5420 & 29.48 & $0.85(0.78-0.94)$ & $0.92(0.82-1.04)$ \\
Predominantly cell-phone users & 2919 & 21.86 & $0.78(0.69-0.88)$ & $0.86(0.75-0.98)$ \\
$P$ (trend) & & & $<.0001$ & .005 \\
\hline
\end{tabular}

*Adjusted for age (years), sex (female or male), ethnicity (non-Hispanic white, non-Hispanic blacks, Mexican Americans, or others), smoking categories (never, former, or current), alcohol intake (never drinker, former drinker, current light drinker, current moderate drinker, current heavy drinker, or unknown drinking status), body mass index $\left(\mathrm{kg} / \mathrm{m}^{2}\right)$, education ( $<$ high school, high school, or $>$ high school), landline use (absent or present), and moderate physical activity (times/week).

${ }^{\dagger}$ All estimates were weighted to account for the complex survey design and survey nonresponse, using the sample adult record weight, to represent the U.S. civilian noninstitutionalized population aged $\geq 18$ years.

smoking, alcohol consumption, BMI, education, physical activity, and landline use. This inverse association between cell-phone usage and hypertension was found to be stronger in women, those aged $<60$ years, whites, and those with BMI $<25 \mathrm{~kg} / \mathrm{m}^{2}$. This is the first study to examine the association between cell-phone use and hypertension in a population-based sample of US adults.
In the current study, we used self-reported hypertension to define the presence of hypertension, since NHIS did not have measured blood pressure. We believe that this is an important study limitation, since recent estimates from the US National Health and Nutritional Examination Surveys suggest that nearly $22 \%$ of truly hypertensive subjects are unaware of their condition [24]. This lack of 
TABLE 3: Association between cell-phone use and hypertension by age groups.

\begin{tabular}{|c|c|c|c|c|}
\hline Cell-phone use & Sample size & $\begin{array}{c}\text { Weighted } \\
\text { prevalence, } \%\end{array}$ & $\begin{array}{l}\text { Age-adjusted OR } \\
(95 \% \mathrm{CI})\end{array}$ & $\begin{array}{l}\text { Multivariable OR } \\
\quad(95 \% \mathrm{CI})^{*}\end{array}$ \\
\hline \multicolumn{5}{|l|}{ Age $<60$ years $(n=15336)$} \\
\hline Cell-phone nonusers & 6600 & 20.55 & 1 (Referent) & 1 (Referent) \\
\hline Predominantly landline users & 1938 & 26.83 & $0.93(0.80-1.07)$ & $0.98(0.84-1.16)$ \\
\hline Dual users of cell phone and landline & 4183 & 21.04 & $0.77(0.68-0.88)$ & $0.85(0.74-0.99)$ \\
\hline Predominantly cell-phone users & 2615 & 18.05 & $0.73(0.63-0.84)$ & $0.82(0.70-0.96)$ \\
\hline$P$ (trend) & & & $<.0001$ & .004 \\
\hline \multicolumn{5}{|l|}{ Age $\geq 60$ years $(n=5799)$} \\
\hline Cell-phone nonusers & 2590 & 63.71 & 1 (Referent) & 1 (Referent) \\
\hline Predominantly landline users & 1668 & 61.81 & $1.00(0.86-1.16)$ & $1.16(0.88-1.53)$ \\
\hline Dual users of cell phone and landline & 1237 & 58.04 & $0.87(0.74-1.01)$ & $0.99(0.75-1.32)$ \\
\hline Predominantly cell-phone users & 304 & 54.61 & $0.77(0.58-1.02)$ & $0.88(0.61-1.27)$ \\
\hline$P($ trend $)$ & & & .02 & .1 \\
\hline \multicolumn{5}{|c|}{$\begin{array}{l}\text { * Adjusted for sex (female or male), ethnicity (non-Hispanic white, non-Hispanic blacks, Mexican Americans, or others), smoking categories (never, former, } \\
\text { or current), alcohol intake }(\text { never drinker, former drinker, current light drinker, current moderate drinker, current heavy drinker, or unknown drinking } \\
\text { status), body mass index }\left(\mathrm{kg} / \mathrm{m}^{2}\right) \text {, education (<high school, high school, or }>\text { high school), landline use (absent or present), and moderate physical activity } \\
\text { (times/week); } P \text { interaction }=0.99 \text {. } \\
{ }^{\dagger} \text { All estimates were weighted to account for the complex survey design and survey nonresponse, using the sample adult record weight, to represent the U.S. } \\
\text { civilian noninstitutionalized population aged } \geq 18 \text { years. }\end{array}$} \\
\hline
\end{tabular}

TABLE 4: Association between cell-phone use and hypertension by gender.

\begin{tabular}{|c|c|c|c|c|}
\hline Cell-phone use & Sample size & $\begin{array}{c}\text { Weighted } \\
\text { prevalence, \% }\end{array}$ & $\begin{array}{c}\text { Age-adjusted OR } \\
(95 \% \mathrm{CI})\end{array}$ & $\begin{array}{l}\text { Multivariable OR } \\
(95 \% \mathrm{CI})^{*}\end{array}$ \\
\hline \multicolumn{5}{|l|}{$\operatorname{Men}(n=9,310)$} \\
\hline Cell-phone nonusers & 4218 & 28.92 & 1 (Referent) & 1 (Referent) \\
\hline Predominantly landline users & 1444 & 42.31 & $1.12(0.94-1.33)$ & $1.07(0.87-1.31)$ \\
\hline Dual users of cell phone and landline & 2343 & 30.35 & $0.98(0.86-1.11)$ & $0.95(0.81-1.12)$ \\
\hline Predominantly cell-phone users & 1305 & 23.22 & $0.88(0.74-1.04)$ & $0.87(0.72-1.06)$ \\
\hline$P($ trend $)$ & & & .1 & .09 \\
\hline \multicolumn{5}{|l|}{ Women $(n=11,825)$} \\
\hline Cell-phone nonusers & 4972 & 35.92 & 1 (Referent) & 1 (Referent) \\
\hline Predominantly landline users & 2162 & 43.48 & $0.88(0.78-1.00)$ & $1.05(0.87-1.26)$ \\
\hline Dual users of cell phone and landline & 3077 & 28.83 & $0.75(0.66-0.86)$ & $0.90(0.75-1.08)$ \\
\hline Predominantly cell-phone users & 1614 & 20.76 & $0.70(0.59-0.83)$ & $0.84(0.68-1.04)$ \\
\hline$P($ trend $)$ & & & $<.0001$ & .03 \\
\hline
\end{tabular}

* Adjusted for age (years), ethnicity (non-Hispanic white, non-Hispanic blacks, Mexican Americans, or others), smoking categories (never, former, or current), alcohol intake (never drinker, former drinker, current light drinker, current moderate drinker, current heavy drinker, or unknown drinking status), body mass index $\left(\mathrm{kg} / \mathrm{m}^{2}\right)$, education (<high school, high school, or $>$ high school), landline use (absent or present), and moderate physical activity (times/week); $P$ interaction $=.98$

${ }^{\dagger}$ All estimates were weighted to account for the complex survey design and survey nonresponse, using the sample adult record weight, to represent the U.S. civilian noninstitutionalized population aged $\geq 18$ years.

blood pressure measurement may have resulted in outcome misclassification. Since hypertension status was assessed independently of a person's cell-phone use, we believe that this misclassification is more likely to be nondifferential and likely to underestimate a true association. However, we cannot entirely rule out the possibility that our findings are overestimate; that is, there is actually no protective association between cell-phone use and hypertension if there were no bias.
Few experimental studies have examined the association between cell-phone usage and blood pressure [21, 25]. Braune et al. noted a significant increase in systolic and diastolic BP in a small group of ten healthy volunteers exposed to EMF from a global system for satellite communications (GSM) cell phone compared with placebo exposure [21]. Vangelova et al. reported significantly higher levels of systolic and diastolic blood pressure in a group of 100 broadcasting and TV station operators exposed to EMF [25]. 
TABLE 5: Association between cell-phone use and hypertension by race/ethnicity.

\begin{tabular}{|c|c|c|c|c|}
\hline Cell-phone use & Sample size & Weighted prevalence, $\%$ & Age-adjusted OR (95\% CI) & Multivariable OR $(95 \% \mathrm{CI})^{*}$ \\
\hline \multicolumn{5}{|l|}{ Whites $(n=12,796)$} \\
\hline Cell-phone nonusers & 5100 & 34.61 & 1 (Referent) & 1 (Referent) \\
\hline Predominantly landline users & 2498 & 43.88 & $1.02(0.91-1.15)$ & $1.08(0.92-1.26)$ \\
\hline Dual users of cell phone and landline & 3480 & 29.83 & $0.87(0.78-0.97)$ & $0.93(0.80-1.09)$ \\
\hline Predominantly cell-phone users & 1718 & 21.42 & $0.73(0.63-0.85)$ & $0.81(0.68-0.96)$ \\
\hline$P($ trend $)$ & & & $<.0001$ & .003 \\
\hline \multicolumn{5}{|l|}{ Others $(n=8,339)$} \\
\hline Cell-phone nonusers & 4090 & 30.34 & 1 (Referent) & 1 (Referent) \\
\hline Predominantly landline users & 1108 & 41.06 & $0.97(0.81-1.17)$ & $0.97(0.78-1.20)$ \\
\hline Dual users of cell phone and landline & 1940 & 28.87 & $0.83(0.70-0.98)$ & $0.86(0.71-1.04)$ \\
\hline Predominantly cell-phone users & 1201 & 22.48 & $0.88(0.72-1.09)$ & $0.93(0.74-1.18)$ \\
\hline$P($ trend $)$ & & & .05 & .3 \\
\hline
\end{tabular}

TABLE 6: Association between cell-phone use and hypertension by body mass index (BMI) categories.

\begin{tabular}{lcccc}
\hline Cell-phone use & Sample size & $\begin{array}{c}\text { Weighted } \\
\text { prevalence, } \%\end{array}$ & $\begin{array}{c}\text { Age-adjusted OR } \\
(95 \% \text { CI })\end{array}$ & $\begin{array}{c}\text { Multivariable OR } \\
(95 \% \text { CI })^{*}\end{array}$ \\
\hline BMI $<25 \mathrm{~kg} / \mathrm{m}^{2}(n=7,691)$ & & & & \\
Cell-phone nonusers & 3540 & 23.39 & 1 (Referent) & 1 (Referent) \\
Predominantly landline users & 1136 & 31.78 & $0.95(0.77-1.16)$ & $1.05(0.80-1.37)$ \\
Dual users of cell phone and landline & 1889 & 17.95 & $0.79(0.64-0.97)$ & $0.86(0.67-1.12)$ \\
Predominantly cell-phone users & 1126 & 11.55 & $0.62(0.48-0.81)$ & $0.69(0.51-0.94)$ \\
$P$ (trend) & & & .0002 & .007 \\
\hline BMI $\geq 25 \mathrm{~kg} / \mathrm{m}^{2}(n=13,444)$ & & & $1($ Referent $)$ & $1($ Referent $)$ \\
Cell phone nonusers & 5650 & 38.55 & $0.94(0.83-1.06)$ & $0.98(0.85-1.14)$ \\
Predominantly landline users & 2470 & 48.18 & $0.84(0.75-0.94)$ & $0.89(0.77-1.03)$ \\
Dual users of cell phone and landline & 3531 & 35.66 & $0.84(0.73-0.97)$ & $0.89(0.76-1.04)$ \\
Predominantly cell-phone users & 1793 & 28.33 & .0007 & .05 \\
$P$ (trend) & & & \\
\hline
\end{tabular}

* Adjusted for age (years), sex (female or male), ethnicity (non-Hispanic white, non-Hispanic blacks, Mexican Americans, or others), smoking categories (never, former, or current), alcohol intake (never drinker, former drinker, current light drinker, current moderate drinker, current heavy drinker, or unknown drinking status), education (<high school, high school, or > high school), landline use (absent or present), and moderate physical activity (times/week); $P$ interaction $=.07$.

${ }^{\dagger}$ All estimates were weighted to account for the complex survey design and survey nonresponse, using the sample adult record weight, to represent the U.S. civilian noninstitutionalized population aged $\geq 18$ years.

Previous studies examining the relation between occupational EMF exposure and cardiovascular diseases have shown mixed results. While majority of the studies have shown a null association $[11,15-18]$, some have shown a positive association $[12,26]$, and one has shown a protective association [27]. Savitz et al. reported a positive association between occupational EMF exposure and cardiovascular mortality in a large cohort of 138,903 male electric utility workers from five US companies [12]. Sastre et al. found that exposure to intermittent $60-\mathrm{Hz}$ magnetic fields reversibly reduces the normal variability of the heart rate in laboratory studies of volunteers [26]. Solenova et al. reported lower levels of all-cause and cardiovascular mortality in TV workers exposed to EMF [27].

In the current study, cell-phone usage was found to be protectively associated with hypertension. It is possible that the effects of cell-phone usage could reduce BP due to an increase in parasympathetic activity and reduction in sympathetic activity originating in the brainstem [28]. Another possibility is that cell phones increase and sustain the social networks of the users, reducing stress and establishing greater connectedness of the users with their communities. This has been previously reported to be protectively associated with cardiovascular disease mortality $[29,30]$, and following this, 


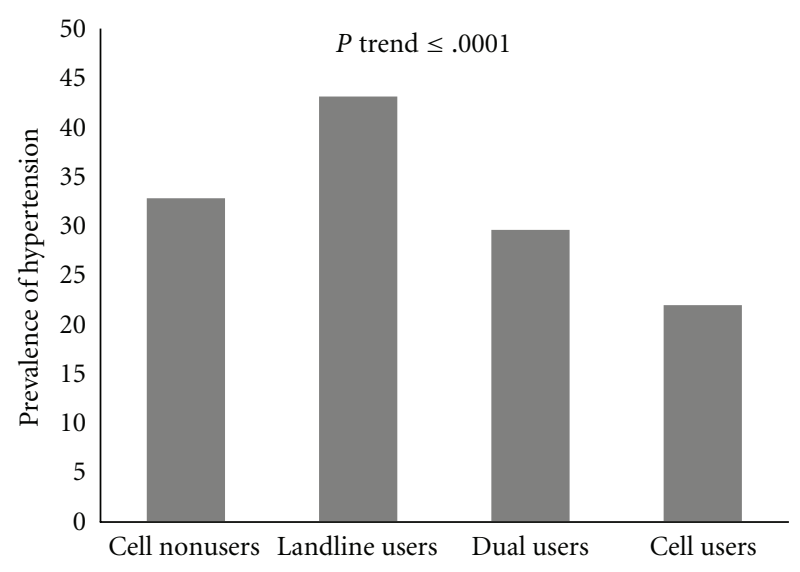

Figure 1: Prevalence of self-reported hypertension by cell-phone use categories.

we hypothesize that it may reduce the risk of hypertension as well. Finally, it is possible that our findings are due to chance. There is a need for longitudinal studies to examine the effect of cell-phone usage on longitudinal changes in blood pressure and hypertension development to refute or validate our findings. Future studies should also examine if there are differential effects for different mobile technologies such as GSM and code division multiple access (CDMA) phones.

The strengths of our study include a large sample size and availability of information on potential confounders. Our study has several limitations. First, as discussed above, our assessment of cell-phone usage and hypertension though self-reported questionnaire data may have resulted in misclassification bias. Second, a measure of blood pressure as a continuous variable would have greatly increased the impact of this study. We recommend that future studies examining the association between cell-phone use and hypertension should include measured blood pressure in addition to selfreported hypertension diagnosis to confirm if our findings are true. Third, we do not have information on EMF exposure from other sources (including cordless phones, radio, television, and microwave oven) that could potentially confound the association between cell phone and hypertension. Fourth, the lack of information on frequency and duration of calls limits any "dose response" to be evaluated. Fifth, while the large sample size allows for correction of potential confounders, it is possible that cell-phone use is different in categories of age, gender, race/ethnicity, and physical activity all of which are known to influence the prevalence of hypertension. Finally, the cross-sectional nature of the study limits any temporal relationship to be ascertained.

In conclusion, we found that cell-phone usage was inversely associated with self-reported hypertension in a nationally representative sample of US adults. Future research should investigate this relationship in prospective studies to provide more insight into the association.

\section{Conflict of Interests}

There are no conflict of interests related to this paper.

\section{Guarantor Statement}

"The guarantor, A. Shankar, accepts full responsibility for the work and/or the conduct of the study, had access to the data, and controlled the decision to publish".

\section{Acknowledgment}

This study was funded by an American Heart Association national Clinical Research program grant (A. Shankar).

\section{References}

[1] "CTIA semi-annual wireless industry survey," July 2010, http://www.ctia.org/advocacy/research/index.cfm/AID/10316.

[2] K. J. Rothman, "Health effects of mobile telephones," Epidemiology, vol. 20, no. 5, pp. 653-655, 2009.

[3] "Report of the independent expert group on mobile phones," 2001, http://www.iegmp.org.uk.

[4] A. W. Preece, G. Iwi, A. Davies-Smith et al., "Effect of a 915$\mathrm{MHz}$ simulated mobile phone signal on cognitive function in man," International Journal of Radiation Biology, vol. 75, no. 4, pp. 447-456, 1999.

[5] M. Koivisto, A. Revonsuo, C. Krause et al., "Effects of 902 $\mathrm{MHz}$ electromagnetic field emitted by cellular telephones on response times in humans," NeuroReport, vol. 11, no. 2, pp. 413-415, 2000.

[6] R. Huber, V. Treyer, A. A. Borbély et al., "Electromagnetic fields, such as those from mobile phones, alter regional cerebral blood flow and sleep and waking EEG," Journal of Sleep Research, vol. 11, no. 4, pp. 289-295, 2002.

[7] V. G. Khurana, C. Teo, M. Kundi, L. Hardell, and M. Carlberg, "Cell phones and brain tumors: a review including the longterm epidemiologic data," Surgical Neurology, vol. 72, no. 3, pp. 205-214, 2009.

[8] L. Hardell and M. Carlberg, "Mobile phones, cordless phones and the risk for brain tumours," International Journal of Oncology, vol. 35, no. 1, pp. 5-17, 2009.

[9] J. Schüz, E. Böhler, G. Berg et al., "Cellular phones, cordless phones, and the risks of glioma and meningioma (Interphone Study Group, Germany)," American Journal of Epidemiology, vol. 163, no. 6, pp. 512-520, 2006.

[10] P. D. Inskip, R. N. Hoover, and S. S. Devesa, "Brain cancer incidence trends in relation to cellular telephone use in the United States," Neuro-Oncology, vol. 12, no. 11, pp. 1147-1151, 2010.

[11] C. Johansen, "Electromagnetic fields and health effectsepidemiologic studies of cancer, disease of the central nervous system and arrhythmia-related heart disease," Scandinavian Journal of Work, Environment and Health, vol. 30, supplement 1, pp. 1-80, 2004.

[12] D. A. Savitz, D. Liao, A. Sastre, R. C. Kleckner, and R. Kavet, "Magnetic field exposure and cardiovascular disease mortality among electric utility workers," American Journal of Epidemiology, vol. 149, no. 2, pp. 135-142, 1999.

[13] Z. Tabor, J. Michalski, and E. Rokita, "Influence of $50 \mathrm{~Hz}$ magnetic field on human heart rate variablilty: linear and nonlinear analysis," Bioelectromagnetics, vol. 25, no. 6, pp. 474-480, 2004.

[14] S. Szmigielski, A. Bortkiewicz, E. Gadzicka, M. Zmyslony, and R. Kubacki, "Alteration of diurnal rhythms of blood pressure and heart rate in workers exposed to radiofrequency 
electromagnetic fields," Blood Pressure Monitoring, vol. 3, no. 6, pp. 323-330, 1998.

[15] J. Sahl, G. Mezei, R. Kavet et al., "Occupational magnetic field exposure and cardiovascular mortality in a cohort of electric utility workers," American Journal of Epidemiology, vol. 156, no. 10, pp. 913-918, 2002.

[16] T. Sorahan and L. Nichols, "Mortality from cardiovascular disease in relation to magnetic field exposure: findings from a study of UK electricity generation and transmission workers, 1973-1997," American Journal of Industrial Medicine, vol. 45, no. 1, pp. 93-102, 2004.

[17] A. R. Cooper, E. van Wijngaarden, S. G. Fisher, M. J. Adams, M. G. Yost, and J. D. Bowman, "A population-based cohort study of occupational exposure to magnetic fields and cardiovascular disease mortality," Annals of Epidemiology, vol. 19, no. 1, pp. 42-48, 2009.

[18] G. Mezei, D. Cher, M. Kelsh, C. Edinboro, P. Chapman, and R. Kavet, "Occupational magnetic field exposure, cardiovascular disease mortality, and potential confounding by smoking," Annals of Epidemiology, vol. 15, no. 8, pp. 622-629, 2005.

[19] F. Feihl, L. Liaudet, and B. Waeber, "The macrocirculation and microcirculation of hypertension," Current Hypertension Reports, vol. 11, no. 3, pp. 182-189, 2009.

[20] A. V. Chobanian, G. L. Bakris, H. R. Black et al., "The Seventh Report of the Joint National Committee on Prevention, Detection, Evaluation, and Treatment of High Blood Pressure: the JNC 7 report," Journal of the American Medical Association, vol. 289, no. 19, pp. 2560-2572, 2003.

[21] S. Braune, C. Wrocklage, J. Raczek, T. Gailus, and C. H. Lücking, "Resting blood pressure increase during exposure to a radio-frequency electromagnetic field," Lancet, vol. 351, no. 9119, pp. 1857-1858, 1998.

[22] T. Magnussen, "EMF: when it is beneficial, when it is adverse," January 2011, http://www.icswebsite.com/emf/emfissues/emfissuessummary.html.

[23] National Health Interview Survey, “Questionnaires, Datasets, and Related Documentation," 2010, http://ftp.cdc.gov/pub/ Health_Statistics/NCHS/Survey_Questionnaires/NHIS/2008/ English/QADULT.pdf.

[24] Y. Ostchega, S. S. Yoon, J. Hughes, and T. Louis, "Hypertension awareness, treatment, and control—continued disparities in adults: United States, 2005-2006," NCHS Data Brief, no. 3, pp. $1-8,2008$.

[25] K. Vangelova, C. Deyanov, and M. Israel, "Cardiovascular risk in operators under radiofrequency electromagnetic radiation," International Journal of Hygiene and Environmental Health, vol. 209, no. 2, pp. 133-138, 2006.

[26] A. Sastre, M. R. Cook, and C. Graham, "Nocturnal exposure to intermittent $60 \mathrm{~Hz}$ magnetic fields alters human cardiac rhythm," Bioelectromagnetics, vol. 19, no. 2, pp. 98-106, 1998.

[27] L. G. Solenova, E. G. Dymova, and N. Fir, "General and oncologic mortality in TV workers," Meditsina Truda I Promyshlennaya Ekologiya, no. 5, pp. 20-24, 2004.

[28] J. L. Reid, "Hypertension and the brain," British Medical Bulletin, vol. 50, pp. 371-380, 1994.

[29] I. Kawachi, G. A. Colditz, A. Ascherio et al., "A prospective study of social networks in relation to total mortality and cardiovascular disease in men in the USA," Journal of Epidemiology and Community Health, vol. 50, no. 3, pp. 245-251, 1996.

[30] P. M. Eng, E. B. Rimm, G. Fitzmaurice, and I. Kawachi, "Social ties and change in social ties in relation to subsequent total and cause-specific mortality and coronary heart disease incidence in men," American Journal of Epidemiology, vol. 155, no. 8, pp. 700-709, 2002. 


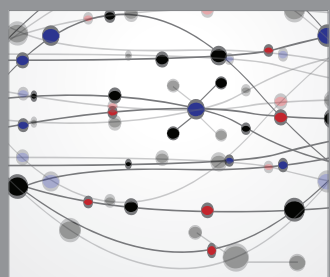

The Scientific World Journal
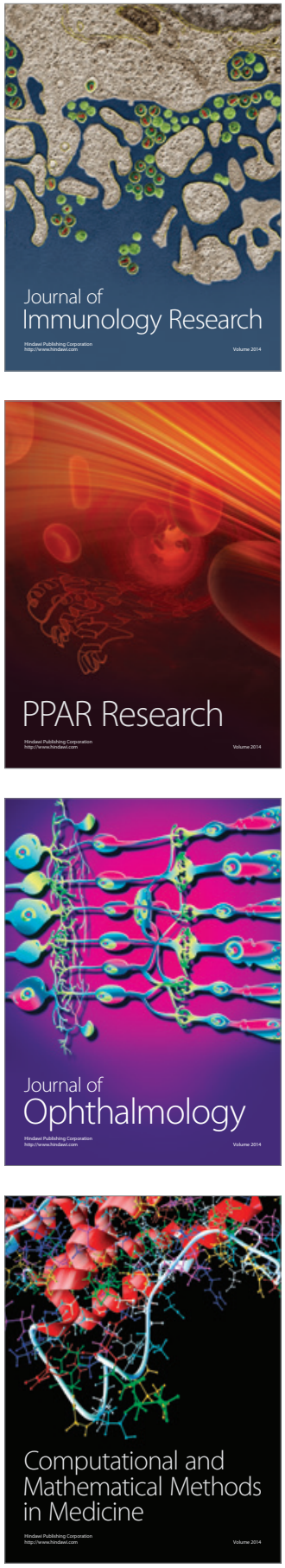

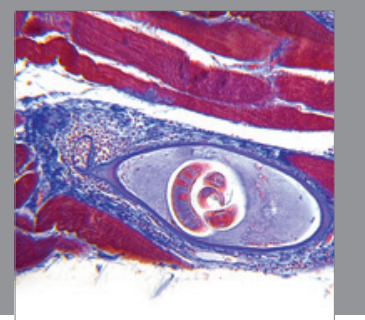

Gastroenterology

Research and Practice
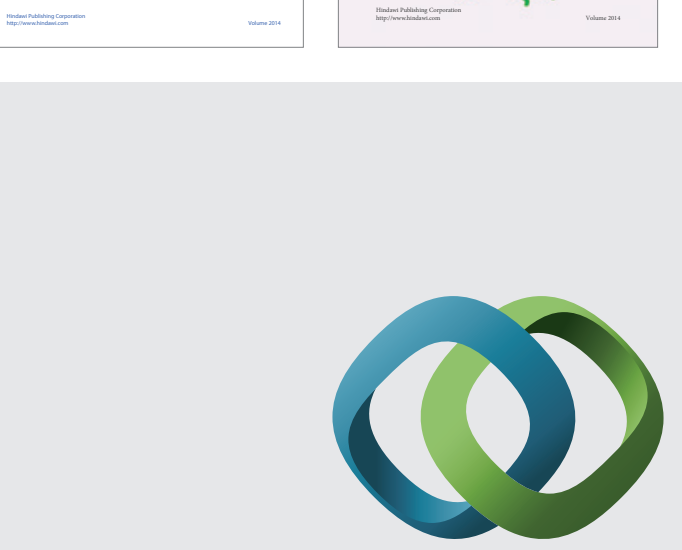

\section{Hindawi}

Submit your manuscripts at

http://www.hindawi.com
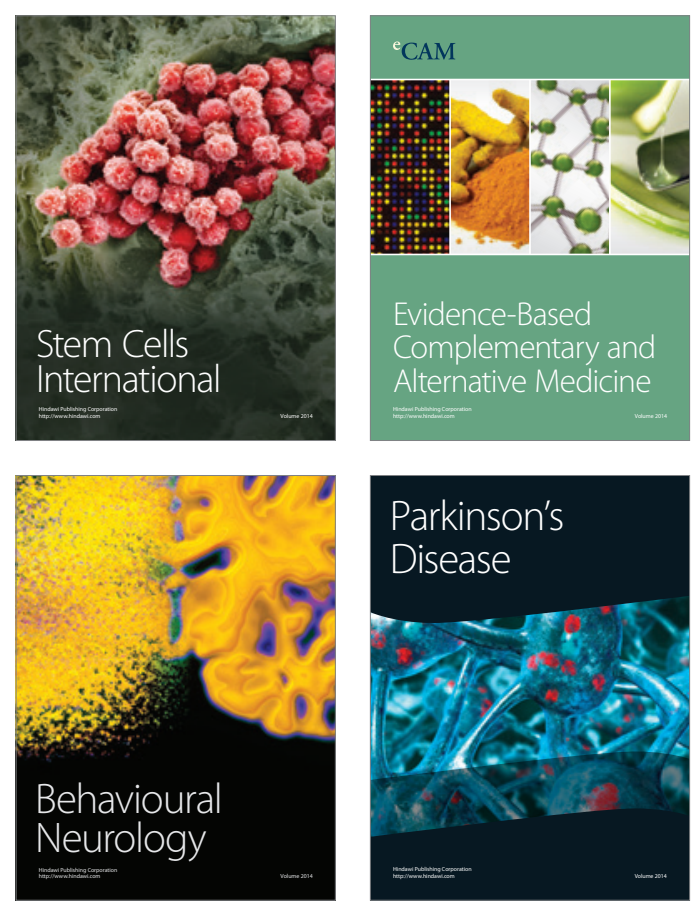

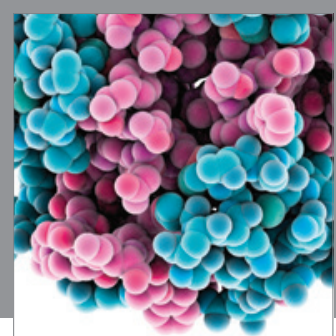

Journal of
Diabetes Research

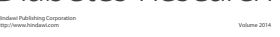

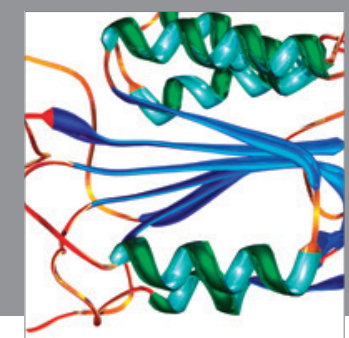

Disease Markers
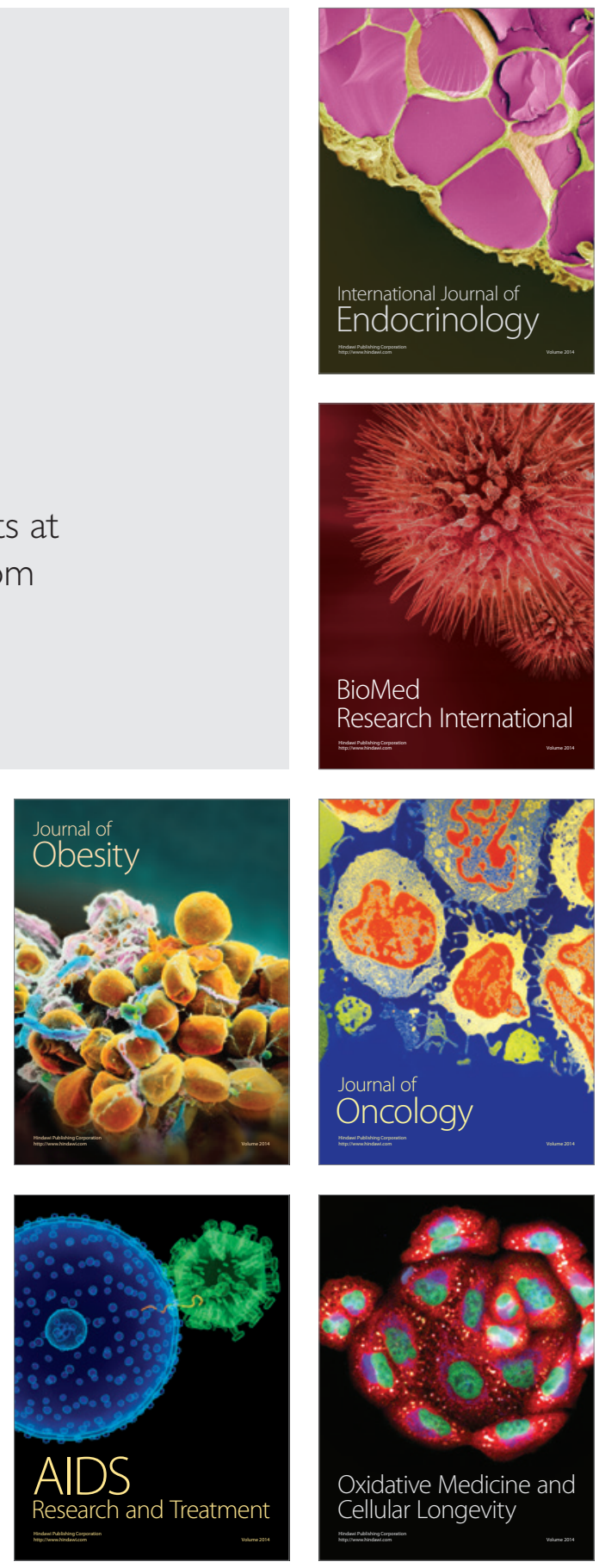